\title{
EFFECT OF PLANT WATER EXTRACTS AND PLANT OILS ON WHITE MOULD DISEASE OF BEANS
}

\author{
M.M. Ammar ${ }^{(1)}$, E.Z. Khalifa ${ }^{(1)}$, Sanaa R. El-Khateeb ${ }^{(1)}$ and A.A. Shaban ${ }^{(2)}$ \\ (1) Agriculture Botany Department, Faculty of Agriculture, Menoufia University, Egypt. \\ (2) General Organization for Control Export \& Import, International Cairo Airport, Egypt.
}

Received: Nov. 1, 2016

Accepted: Dec. 1, 2016

\begin{abstract}
Water extracts and oils of garlic, onion, citrus, camphor and clove reduced the linear growth of S. sclerotiorum and clove extract was the best one. Generally, increasing the concentration of any used extract resulted more reduction of the fungal growth. However, under greenhouse and artificial soil infestation conditions both garlic and clove extracts and oils were the best for reducing damping-off and increasing the survival plants. Under field and natural soil infestation conditions, clove water extract and garlic oil gave the best results of disease reduction and improved yield production; significantly; in comparison with control (-) treatments, of Giza 3 bean cultivar.
\end{abstract}

Key words: Phaseolus vulgaris, White mould, Sclerotinia sclerotiorum, Plant oils, Plant water extracts. (Allium sativum), (Allium cepa) (Citrus reticulated), (Eucalyptus globulus) and (Lanthus carphyllus).

\section{INTRODUCTION}

Bean (Phaseolus vulgaris L.) belonging to the family Fabaceae, is considered one of the most important leguminous crops cultivated in Egypt. Where their seeds and pods are rich in calcium, some vitamins, proteins, mineral salts, some amino acids especially lysine and others. It is characterized by its well-growth in the moderate regions. It's cultivated for use as green pods or dried seeds. Recently, it's highly demanded for exporting to the European market (HEIA, 2003). The cultivated area of beans was increased where it was 46048 feddan in the season $1999 / 2000,60562$ feddan in the season 2007/2008, 65606 feddan in the season 2009/2010 and became 168979 feddan in the season 2013/2014 (Statistics Dept. Ministry of Agriculture, Egypt). White mould, caused by the plant pathogenic fungus Sclerotinia sclerotiorum (Lib.) de Bary, is the most important disease attacks green beans and dry beans, tomatoes, potatoes, green peppers, canola and many other crops Pascual et al. (2010) and Vural and Soylu (2012). The disease has been economically more important in snap beans than dry beans because in addition to direct losses in the field, detection of more than 2 per cent diseased pods in a truckload at the processing plant may result in rejection of the whole load.

Water extracts of garlic, onion, citrus, camphor and clove at different concentrations were tested against $S$. sclerotiorum .Results shown that all plant extracts gave good levels of control the pathogen.

Clove water extract showed the best efficiency on the other hand Onion water extract showed the lowest efficiency against S. sclerotiorum Patil and Srikant (2002) and Aba Alkhail (2005).

Oils of garlic, onion, citrus, camphor, clove and capsicum were tested to control white mould (S. sclerotiorum) generally; all tested plant oils reduced the infection with white mould and increased yield production than control (-) treatment. Garlic oil followed by clove oil showed the best effects for reducing the infection, onion oil was the lowest efficiency against $S$. sclerotiorum (Byron and Hall (2002), Seda and Moram (2002) and Benkeblia (2004)). 
The aim of this study was to determine the biological effectiveness, in vitro, greenhouse and field of plant water extracts and plant oils against white mould $S$. sclerotiorum (Lib.) de Bary during two seasons (2014 - 2015).

\section{MATERIALS AND METHODS \\ 1. Isolation, purification and identification of the causal organism:}

Samples of diseased bean plants showed white mould symptoms were collected from different localities at 2013 growing season. Seven governorates i.e., Alexandria, Behaira, Giza, Gharbia, Ismailia, Menoufia and Qalubia were assembled. Three localities of Menoufia (Ashmoun, Menouf and Sadat City) were included. The obtained samples (stems and / or pods) were individually washed thoroughly with tap water, sterilized with $3 \%$ sodium hypochlocide for 2 minutes, washed several times with sterilized distilled water and dried between sterilized filter papers. Sterilized samples were cut into small pieces, put on PDA medium in Petri dishes; separately and incubated at $20^{\circ} \mathrm{C}$ for two days. The abundant growth was purified using hyphal tip technique. Pure cultures were identified at Botany Department, Faculty of Agriculture, Menoufia University.

\section{Laboratory experiments:}

Laboratory experiments were conducted at Plant Pathology Laboratory, Botany Department, Faculty of Agriculture, Menoufia University, Shebin El-Kom, Egypt. In these studies; plant water extracts and plant oils were tested against $S$. sclerotiorum. Complete randomize design with 3 replicates was followed using PDA medium. The materials were prepared as following:

\subsection{Plant water extracts:}

Cloves of garlic (Allium sativum), bulbs of onion (A. cepa) and leaves of citrus (Citrus reticulated), camphor (Eucalyptus globulus) and clove (Lanthus carphyllus) were separately cut into small pieces. Hundred gram of each were soaked in $250 \mathrm{ml}$ sterilized water and heated at $90^{\circ} \mathrm{C}$ for $20 \mathrm{~m}$. Individual filtrates were diluted with sterilized distilled water to be one liter as stock solution. The concentrations of 30,50 and $100 \mathrm{gm} / \mathrm{L}$ of these extracts were examined (Mutwally et al., 2010).

\subsection{Plant oils:}

Oils of garlic, onion, citrus, camphor, clove and capsicum were obtained from ElGomhouria Company for Oils and Pharmacutical Industries, Cairo, Egypt. The concentrations of 1,3 and $5(\mathrm{gm} / \mathrm{L})$ of each oil were prepared using sterilized distilled water and as dissolving material.

\section{Green-house experiments:}

These experiments were carried out at the Faculty of Agriculture, Menoufia University, Shebin El-Kom, Egypt. The individual effects of plant extracts and plant oils were tested under artificial soil infestation conditions. Sterilization and soil infestation methods were conducted as mentioned in pathogenicity test experiment. Three pots $(25 \mathrm{~cm}$ in diameter) assembled each treatment and five seeds were planted in the pot. Control (-) treatment (infested soil with the pathogen only). The emerged plants were sprayed 3 times; 15,30 and 45 days after planting date $\left(1^{\text {st }}\right.$ of September 2014 and 2015).

Data recorded were pre-emergence damping-off (one month after planting), post emergence damping-off (45 days after planting) and the average of the survived plant (75 days after planting). The data were statistically analyzed and significance among means was assessed by least significant difference (LSD) at $5 \%$ probability level using SAS ANOVA program V.9 (Anonymous, 2014).

\section{Field experiments:}

Field experiments were carried out at Sunsaft village, Menouf, Menoufia Governorate, Egypt in naturally heavily infested soil with $S$. sclerotiorum. The experiments were arranged in randomized 
complete block design where Giza 3 bean cultivar was tested. Three plots of $(2 \times 3 \mathrm{~m}$, assembled each treatment which planted at the first of September 300 plants / each) both at 2014 and 2015.

Different control method treatments were applied by spraying the plants three times. These were 15 days after seeding, one month later and two months later.

\section{Data recorded:}

1. Pre- and post-emergence damping-off (20 days after planting).

2. Percentage of infection.

3. Severity of infection.

The scale of $0-5$ was used to estimate the severity of infection where: (0: healthy, 1 : 20\%, 2: 40\%, 3: 60\%, 4: $80 \%$ and 5: $100 \%$ ).

Using the following formula (Soliman et al., 1988):

$$
\text { S.I. }=\frac{\mathrm{a} \times \mathrm{b}}{\mathrm{N} \times \mathrm{K}} \times 100
$$

Where: a: Number of diseased plants.

b: Infection rate $(0-5)$.

$\mathrm{N}$ : Total number of the plants / plot.

$\mathrm{K}$ : Total infection rates.

4. Average number of pods / plant.

5. Average weight of produced green pods (kg per plot).

\section{RESULTS AND DISCUSSION}

\section{Laboratory experiments:}

The most aggressive isolate (7) was used in the following experiments.

\subsection{Effect of plant extracts on the fungal growth:}

Water extracts of garlic, onion, citrus, camphor and clove at different concentrations were tested against $S$. sclerotiorum on PDA medium. Results shown in Table (1) clear that all tesetd plant extracts reduced the linear growth of the pathogen. Increasing the concentration of any extract gave more reduction of the fungal growth. Clove water extract showed the best results where growth reduction was $49.43, \quad 60.67$ and $75.73 \%$ at the concentrations of 30,50 and $100 \mathrm{gm} / \mathrm{L}$, respectively. Camphor extract came in the second rank and recorded 26.96, 45.73 and $71.91 \%$ growth reduction, respectively with the obvious concentrations. Onion water extract showed the lowest efficiency on reducing the fungal growth. These were also recorded by Kanherkar et al. (2007), ElShahawy (2009) and Morsy et al. (2009).

\subsection{Effect of plant oils on the fungal growth:}

Oils of the abovementioned plants beside capsicum one were also tested to calculate their effects against the growth of $S$. sclerotiorum. All tested oils at all concentrations $(1,3$ and $5 \mathrm{~g} / \mathrm{L}$ ) reduced the linear growth of $S$. sclerotiorum than control, significantly (Table 2). Camphor and garlic oils at the rate of $5 \mathrm{~g} / \mathrm{L}$ completely inhibited the fungal growth $(94.38 \%$ reduction than control). These were followed by citrus, capsicum and clove oils. However, onion oil had the least effect in reducing the fungal growth. Generally, increasing the concentration of any tested oil showed more effect in reducing the growth and vice versa. Such results were achieved by Omidbaigi et al. (2007) and Bakkali et al. (2008).

\section{Greenhouse experiments:}

Under greenhouse and artificial soil infestation conditions with isolate No. 7, different control methods were tested.

\subsection{Effect of plant water extracts on the disease incidence:}

Both garlic and clove extracts were the best for reducing damping-off and increasing the survival plant (80\%), at 2014 growing season (Table 3). In the meantime, plant height was also responded by these applications and recorded 21.33 and 24.00 $\mathrm{cm}$ for garlic and clove extracts, respectively. Camphor extract resulted $60 \%$ survival plants with $21 \mathrm{~cm}$ average plant height. The least effective extract was onion one where it resulted $33.33 \%$ survival plants only. On the other hand, the infested control treatment caused completely death of all seeded plants. 
Ammar, et al.,

Table (1). Effect of plant water extracts on the growth of Sclerotinia sclerotiorum under laboratory conditions.

\begin{tabular}{|c|c|c|c|}
\hline Plant extract & $\begin{array}{l}\text { Conc. } \\
\text { (gm/L) }\end{array}$ & Linear-growth $(\mathrm{cm})$ & Growth reduction (\%) \\
\hline \multirow{3}{*}{ Garlic } & 30 & 7.00 & 21.34 \\
\hline & 50 & 6.83 & 23.25 \\
\hline & 100 & 2.5 & 71.91 \\
\hline \multirow{3}{*}{ Onion } & 30 & 7.50 & 15.73 \\
\hline & 50 & 5.83 & 34.49 \\
\hline & 100 & 5.00 & 43.82 \\
\hline \multirow{3}{*}{ Citrus } & 30 & 6.83 & 23.25 \\
\hline & 50 & 4.50 & 49.43 \\
\hline & 100 & 2.50 & 71.91 \\
\hline \multirow{3}{*}{ Camphor } & 30 & 6.50 & 26.96 \\
\hline & 50 & 4.83 & 45.73 \\
\hline & 100 & 2.50 & 71.91 \\
\hline \multirow{3}{*}{ Clove } & 30 & 4.50 & 49.43 \\
\hline & 50 & 3.50 & 60.67 \\
\hline & 100 & 2.16 & 75.73 \\
\hline \multicolumn{2}{|c|}{ Control(-) } & 8.90 & 0.00 \\
\hline \multicolumn{2}{|c|}{ L.S.D. at $5 \%$} & 2.00 & - \\
\hline
\end{tabular}

Table (2). Effect of plant oils on the growth of Sclerotinia sclerotiorum under laboratory conditions.

\begin{tabular}{|c|c|c|c|}
\hline Plant oil & $\begin{array}{l}\text { Conc. } \\
\text { (gm/L) }\end{array}$ & $\begin{array}{l}\text { Linear growth } \\
(\mathrm{cm})\end{array}$ & Growth reduction (\%) \\
\hline \multirow{3}{*}{ Garlic } & 1 & 3.50 & 60.67 \\
\hline & 3 & 2.83 & 68.20 \\
\hline & 5 & 0.50 & 94.38 \\
\hline \multirow{3}{*}{ Capsicum } & 1 & 5.16 & 42.02 \\
\hline & 3 & 4.16 & 53.25 \\
\hline & 5 & 1.33 & 85.05 \\
\hline \multirow{3}{*}{ Citrus } & 1 & 2.00 & 77.52 \\
\hline & 3 & 1.33 & 85.05 \\
\hline & 5 & 1.00 & 88.76 \\
\hline \multirow{3}{*}{ Camphor } & 1 & 1.16 & 86.96 \\
\hline & 3 & 0.83 & 90.67 \\
\hline & 5 & 0.50 & 94.38 \\
\hline \multirow{3}{*}{ Clove } & 1 & 4.33 & 51.34 \\
\hline & 3 & 3.50 & 60.67 \\
\hline & 5 & 1.66 & 81.34 \\
\hline \multirow{3}{*}{ Onion } & 1 & 4.00 & 55.05 \\
\hline & 3 & 3.50 & 60.67 \\
\hline & 5 & 2.50 & 71.91 \\
\hline \multicolumn{2}{|c|}{ Control(-) } & 8.90 & 0.00 \\
\hline \multicolumn{2}{|c|}{ L.S.D. at $5 \%$} & 2.12 & - \\
\hline
\end{tabular}


Table (3). Effect of plant water extracts on the disease incidence and plant height under greenhouse and artificial soil infestation conditions.

\begin{tabular}{|c|c|c|c|c|c|}
\hline Plant extract & $\begin{array}{l}\text { Conc. } \\
\text { (gm/L) }\end{array}$ & $\begin{array}{l}\text { Pre-emergence } \\
\text { damping-off }\end{array}$ & $\begin{array}{c}\text { Post-emergence } \\
\text { damping-off }\end{array}$ & $\begin{array}{l}\text { Survival } \\
\text { plants (\%) }\end{array}$ & $\begin{array}{l}\text { Plant height } \\
(\mathrm{cm})\end{array}$ \\
\hline & \multicolumn{5}{|c|}{ season 2014} \\
\hline Garlic & 100 & 13.33 & 6.67 & 80.00 & 21.33 \\
\hline Onion & 100 & 46.67 & 20.00 & 33.33 & 18.33 \\
\hline Citrus & 100 & 33.33 & 13.33 & 53.34 & 20.00 \\
\hline Clove & 100 & 13.33 & 6.67 & 80.00 & 24.00 \\
\hline Camphor & 100 & 26.67 & 13.33 & 60.00 & 21.00 \\
\hline \multicolumn{2}{|c|}{ Control (-) } & 73.33 & 26.67 & 0.00 & - \\
\hline \multicolumn{2}{|c|}{ L.S.D. at $5 \%$} & 37.38 & 27.92 & 24.55 & 5.03 \\
\hline & \multicolumn{5}{|c|}{ season 2015} \\
\hline Garlic & 100 & 13.33 & 13.33 & 73.34 & 34.33 \\
\hline Onion & 100 & 20.00 & 26.67 & 53.33 & 30.00 \\
\hline Citrus & 100 & 13.33 & 13.33 & 73.34 & 34.00 \\
\hline Clove & 100 & 6.67 & 13.33 & 80.00 & 38.00 \\
\hline Camphor & 100 & 13.33 & 13.33 & 73.34 & 34.00 \\
\hline \multicolumn{2}{|c|}{ Control (-) } & 46.66 & 46.67 & 6.67 & 10.00 \\
\hline \multicolumn{2}{|c|}{ L.S.D. at $5 \%$} & 22.69 & 18.39 & 25.44 & 15.04 \\
\hline
\end{tabular}

Nearly similar results were achieved at 2015 growing season where clove extract was the most effective against the fungus followed by garlic, citrus and camphor extracts. Plant height was significantly increased than control (-) treatment and the best height were achieved when clove extract was applied.

\subsection{Effect of plant oils on the disease incidence:}

Results present in Table (4) clear that garlic oil (5 g/L) both at 2014 and 2015 growing seasons was superior in controlling white mould disease of bean where it resulted $93.33 \%$ survival plants with the average of $28.33 \mathrm{~cm}$ plant height. This was followed by camphor and clove oils which gave $73.33 \%$ survivals. Onion oil was the least effective one against the disease. On the other hand, all tested oils significantly reduced the disease incidence and increased plant height in comparison with control (-) treatment (infested soil with the pathogen only).

\section{Field experiments:}

Under field and natural soil infestation conditions, the different control methods were tested, both at 2014 and 2015 growing seasons. Field soil was heavily infested with the causal organism, S. sclerotiorum.

\subsection{Effect of plant water extracts on the disease incidence and yield production:}

Results shown in Table (5) indicate that clove extract was the best for controlling the disease and yield production at both seasons. At 2014, infection percent and severity of infection of Giza 3 cultivar recorded 12.66 and $7.66 \%$, respectively. Those of the non-treated control were 53.33 and 21.66, in the same respect. The best yield parameters i.e., average number of pods / plant and yield of the experimental plot, were also resulted in response to clove extract application. They were 32.33 pods / plant and $16.62 \mathrm{~kg}$ green yield / plot. 
Ammar, et al.,

Table (4). Effect of plant oils on the disease incidence and plant height under greenhouse and artificial soil infestation conditions.

\begin{tabular}{|c|c|c|c|c|c|}
\hline Plant oil & $\begin{array}{l}\text { Conc. } \\
\text { (gm/L) }\end{array}$ & $\begin{array}{l}\text { Pre-emergence } \\
\text { damping-off }\end{array}$ & $\begin{array}{l}\text { Post-emergence } \\
\text { damping-off }\end{array}$ & $\begin{array}{c}\text { Survival } \\
\text { plants (\%) }\end{array}$ & $\begin{array}{l}\text { Plant height } \\
(\mathrm{cm})\end{array}$ \\
\hline & \multicolumn{5}{|c|}{ season 2014} \\
\hline Camphor & 5 & 20.00 & 6.67 & 73.33 & 25.66 \\
\hline Onion & 5 & 26.67 & 20.00 & 53.33 & 23.33 \\
\hline Garlic & 5 & 6.67 & 0.00 & 93.33 & 28.33 \\
\hline Capsicum & 5 & 26.67 & 13.33 & 60.00 & 23.33 \\
\hline Clove & 5 & 20.00 & 6.67 & 73.33 & 23.00 \\
\hline Citrus & 5 & 26.67 & 13.33 & 60.00 & 24.00 \\
\hline \multicolumn{2}{|c|}{ Control (-) } & 73.33 & 26.67 & 0.00 & - \\
\hline \multicolumn{2}{|c|}{ L.S.D. at $5 \%$} & 43.69 & 25.94 & 27.99 & 9.58 \\
\hline & \multicolumn{5}{|c|}{ season 2015} \\
\hline Camphor & 5 & 13.33 & 13.33 & 73.34 & 32.00 \\
\hline Onion & 5 & 20.00 & 26.67 & 53.33 & 26.00 \\
\hline Garlic & 5 & 6.67 & 6.67 & 86.66 & 37.33 \\
\hline Capsicum & 5 & 13.33 & 13.33 & 73.34 & 30.67 \\
\hline Clove & 5 & 6.67 & 13.33 & 80.00 & 35.00 \\
\hline Citrus & 5 & 13.33 & 13.33 & 73.34 & 31.33 \\
\hline \multicolumn{2}{|c|}{ Control (-) } & 46.67 & 46.67 & 6.66 & 10.00 \\
\hline \multicolumn{2}{|c|}{ L.S.D. at $5 \%$} & 17.36 & 26.32 & 22.18 & 15.53 \\
\hline
\end{tabular}

Table (5). Effect of plant water extracts on white rot disease incidence and yield production of Giza 3 cultivar under field and natural soil infestation conditions.

\begin{tabular}{|c|c|c|c|c|c|c|}
\hline $\begin{array}{c}\text { Plant } \\
\text { extract }\end{array}$ & $\begin{array}{l}\text { Conc. } \\
\text { (gm/L) }\end{array}$ & $\begin{array}{c}\text { Pre-emergence } \\
\text { damping-off }\end{array}$ & $\begin{array}{l}\text { Percentage of } \\
\text { infection }\end{array}$ & $\begin{array}{c}\text { Severity of } \\
\text { infection }\end{array}$ & $\begin{array}{c}\text { Yield } \\
\left(\mathrm{kg} / \mathrm{cm}^{2}\right)\end{array}$ & $\begin{array}{l}\text { Average No. } \\
\text { of pods/plant }\end{array}$ \\
\hline & \multicolumn{6}{|c|}{2014 season } \\
\hline Garlic & 100 & 15.00 & 16.00 & 8.66 & 15.93 & 29.66 \\
\hline Onion & 100 & 15.66 & 19.66 & 11.66 & 11.43 & 24.66 \\
\hline Citrus & 100 & 17.66 & 17.33 & 11.00 & 13.79 & 31.00 \\
\hline Camphor & 100 & 13.00 & 14.00 & 8.66 & 14.55 & 26.00 \\
\hline Clove & 100 & 8.33 & 12.66 & 7.66 & 16.62 & 32.33 \\
\hline \multicolumn{2}{|c|}{ Control (-) } & 31.33 & 53.33 & 21.66 & 4.31 & 15.66 \\
\hline \multicolumn{2}{|c|}{ L.S.D. at $5 \%$} & 9.89 & 18.89 & 6.49 & 3.02 & 6.48 \\
\hline & \multicolumn{6}{|c|}{2015 season } \\
\hline Garlic & 100 & 8.33 & 19.66 & 12.66 & 11.22 & 22.33 \\
\hline Onion & 100 & 11.33 & 23.33 & 15.66 & 10.25 & 16.33 \\
\hline Citrus & 100 & 9.00 & 20.66 & 14.66 & 10.08 & 20.66 \\
\hline Camphor & 100 & 10.33 & 22.00 & 13.00 & 8.56 & 17.33 \\
\hline Clove & 100 & 8.33 & 16.66 & 10.00 & 12.40 & 26.66 \\
\hline \multicolumn{2}{|c|}{ Control (-) } & 13.33 & 38.00 & 28.00 & 6.31 & 15.00 \\
\hline \multicolumn{2}{|c|}{ L.S.D. at $5 \%$} & 4.19 & 9.43 & 7.36 & 4.48 & 9.84 \\
\hline
\end{tabular}


Garlic and camphor plant extracts were also effective in reducing the disease incidence and improving yield production. However, onion and citrus extracts were less effective but they were better than control (-) treatment, both for disease incidence and yield production.

Nearly similar results were obtained at 2015 growing season .Such results were achieved by Shahnaz et al. (2007) and Islam and Faruq (2012).

\subsection{Effect of plant oils on the disease incidence and yield production:}

Results illustrated in Table (6) indicate that garlic oil $(5 \mathrm{gm} / \mathrm{L})$ was the best for reducing the severity of infection (8.33\%), increasing number of bean pods / plant (24.33) and average yield / plot (13.57 kg), for Giza 3 cultivar at 2015. Clove oil, at the same rate, had the second rank. The same results were obtained at 2014 growing season. Generally, all tested plant oils reduced the infection with white mould and increased yield production than control (-) treatment, significantly. This treatment resulted (51.33\%) dead plants, $28.00 \%$ severity of infection, 15.00 pods / plant and only $6.31 \mathrm{~kg}$ green pods / plot. These were also recorded by Ponce et al. (2004) and ElMetwally et al. (2010).

Table (6). Effect of plant oils on white rot disease incidence and yield production of Giza 3 cultivar under field and natural soil infestation conditions

\begin{tabular}{|c|c|c|c|c|c|c|}
\hline Plant oil & $\begin{array}{l}\text { Conc. } \\
\text { (gm/L) }\end{array}$ & $\begin{array}{c}\text { Pre-emergence } \\
\text { damping-off }\end{array}$ & $\begin{array}{l}\text { Percentage of } \\
\text { infection }\end{array}$ & $\begin{array}{c}\text { Severity of } \\
\text { infection }\end{array}$ & $\begin{array}{c}\text { Yield } \\
\left(\mathrm{kg} / \mathrm{cm}^{2}\right)\end{array}$ & $\begin{array}{c}\text { Average No. o } \\
\text { pods/plant }\end{array}$ \\
\hline & \multicolumn{6}{|c|}{2014 season } \\
\hline Garlic & 5 & 14.33 & 9.00 & 6.66 & 19.17 & 33.33 \\
\hline Capsicum & 5 & 17.33 & 16.66 & 11.33 & 11.82 & 27.33 \\
\hline Citrus & 5 & 16.66 & 15.00 & 10.33 & 14.57 & 22.33 \\
\hline Camphor & 5 & 15.33 & 12.33 & 8.66 & 14.33 & 31.66 \\
\hline Clove & 5 & 15.66 & 10.66 & 8.33 & 13.44 & 26.33 \\
\hline Onion & 5 & 17.00 & 18.66 & 12.33 & 12.89 & 24.66 \\
\hline \multicolumn{2}{|c|}{ Control (-) } & 31.33 & 53.33 & 21.66 & 4.31 & 15.66 \\
\hline \multicolumn{2}{|c|}{ L.S.D. at $5 \%$} & 8.80 & 17.08 & 8.71 & 5.46 & 7.89 \\
\hline & \multicolumn{6}{|c|}{2015 season } \\
\hline Garlic & 5 & 6.00 & 14.00 & 8.33 & 13.57 & 24.33 \\
\hline Capsicum & 5 & 9.33 & 20.00 & 12.33 & 11.94 & 20.00 \\
\hline Citrus & 5 & 9.33 & 20.00 & 15.00 & 10.22 & 20.66 \\
\hline Camphor & 5 & 9.66 & 16.33 & 11.00 & 10.72 & 19.66 \\
\hline Clove & 5 & 7.66 & 15.66 & 10.66 & 12.69 & 22.00 \\
\hline Onion & 5 & 11.00 & 24.00 & 15.00 & 10.07 & 18.66 \\
\hline \multicolumn{2}{|c|}{ Control (-) } & 13.33 & 38.00 & 28.00 & 6.31 & 15.00 \\
\hline \multicolumn{2}{|c|}{ L.S.D. at $5 \%$} & 3.86 & 6.01 & 4.38 & 3.55 & 6.63 \\
\hline
\end{tabular}




\section{REFERENCES}

Aba Alkhail, A.A. (2005). Antifungal activity of some extracts against some plant pathogenic fungi. Pakistan Journal of Biological Sciences, 8 (3): $413-417$.

Anonymous, (2014). Statistical Analysis. SAS Users Guide: Statistices . SAS Institute Inc. Editors, Cary, NC, 27513, USA.

Bakkali, F., S. Averbeck, D. Averbeck and M. Idaomar (2008). Biological effects of essential oils. Food and Chemical Toxicology, 46 (2): $446-475$.

Benkeblia, N. (2004). Antimicrobial activity of essential oils extracts of various onion (Allium cepa) and garlic (Allium sativum). Lebensmittel Wissenehaft und Technologi, 37: 263 - 268.

Byron, E.M. and A.M. Hall (2002). Inhibition of common cereal pathogenic fungi by clove oil and eucalyptus oil. The Bcpc Conference, Pests and Diseases, Vol. 1 and 2: $765-768 .{ }^{*}$

El-Metwally, M.A., K.M. Ghanem and K.M. Abd El-Hai (2010). Improving the performance of faba bean and controlling of chocolate spot disease using biocompounds. Plant Pathology Journal, 9: $169-178$.

El-Shahawy, E.L. (2009). Untraditional control methods of white and gray moulds in green bean pods in Egypt. M.Sc. Thesis, Fac. Agric., Cairo Univ., p. 176.

HEIA, Home Economics Institute of Australia (2003). HEIA Newsletter. Issue 22, July 2003, Egypt.

Islam, M.T. and A.N. Faruq (2012). Effect of some medicinal plant extracts on damping-off disease of winter vegetable. World Applied Sciences Journal, 17 (11): $1498-1503$.

Kanherkar, S.H., N.H. Shahare and A.U. Pachkhede (2007). Efficacy of some plant extracts against Fusarwa oxysporium. Journal of Plant Disease Sciences, 2 (2): $224-225$.

Morsy, S.M., E.A. Drgham and G.M.
Mohamed (2009). Effect of garlic and onion extracts or their intercropping, on suppressing damping-off and powdery mildew diseases and growth characteristics of cucumber. Egyptian Journal of Phytopathology, 37 (1): 35 46.

Mutwally, H.M.A., M.A. Omar and M. Bedaiwy (2010). Microsporum gallinae growth response to some plant extracts. http://uqu.edu.sa/page/ar/2153.

Omidbaigi, R., M. Yahazadeh, R. Zare and $\mathrm{H}$. Taheri (2007). The in vitro action of essential oils on Aspergillus jlavus. Journal of Essential Oil Bearing Plants, $10(1): 46-52$.

Pascual, A.A. Campa and E. Pérez-Vega (2010). Screening Common Bean for Resistance to Four $S$. sclerotiorum Isolates Collected in Northern Spain. Plant Disease, 94: 885 - 889.

Patil, V.S. and K. Srikant (2002). Bio-efficacy of certain botanicals against colony growth and spore germination of Exserohilum hawaiiensis a causal agent of leaf blight of wheat. Kamataka Journal of Agricultural Sciences, 15 (2): 391 396.

Ponce, A.G., C.D. Valle and S.I. Roura (2004). Shelf life of leafy vegetables treated with natural essential oils. Journal of Food Sci., 69 (2): FMS50 - FMS56.

Seda, H. A. and G.S. Moram (2002). Antimicrobial effect of some plant essential oils against some of microorganisms. Annals of Agricultural Science, Moshtohor, 38 (3): 1615 - 1622.

Shahnaz, D., S.M. Younus, T. Marium and M.J. Tariq (2007). Use of Eucalyptus sp., in control of root infecting fungi on mung bean and chick-pea. Pakistan Journal of Botany, 39 (3): 975 - 979.

Soliman, N. K., M. S. Mikhaili, P. K. Harb and E. M. Khalil (1988). Response of broad bean plants infected with Rhizoctonia solani to application of growth regulators and calcium. Egypt. J. Phytopathol., 20 (1): $1-11$. 
دراسة تأثير المستخلصات المائية والزيوت النباتية على مرض العفن الأبيض فى الفاصوليا

محمد محمد بيومى عمار (1) ،السعيد ذكى خليفه(1)، سناء رمضان الخطيب(1) ،

أحمد شعبان عبدالحكم (2)

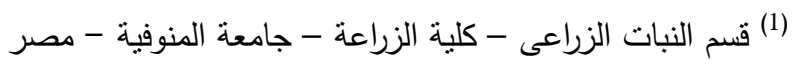

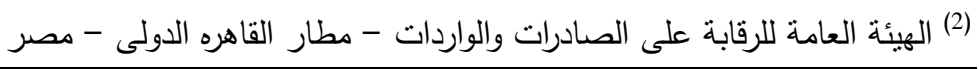

\section{الملخص العربى}

يهدف هذا البحث إلى مكافحه مرض العفن الأبيض فى الفاصوليا باستخدام مركبات صديقة للبيئة بديلة عن

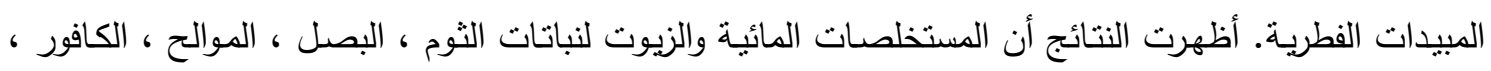
الثطة والقرنفل تختزل نمو الفطر اسكليروتينيا اسكليروتيورم عند تتميته على بيئه اجار البطاطس ، وكان أفضلها

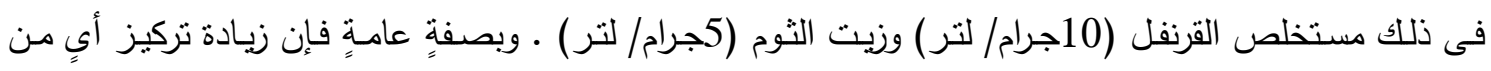

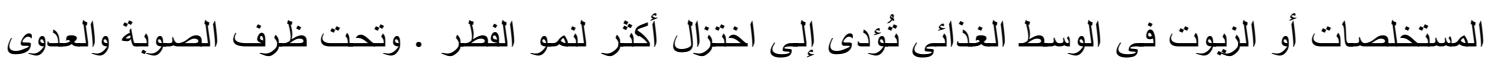

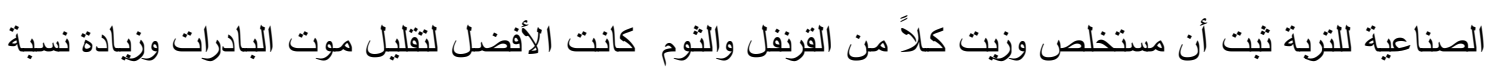

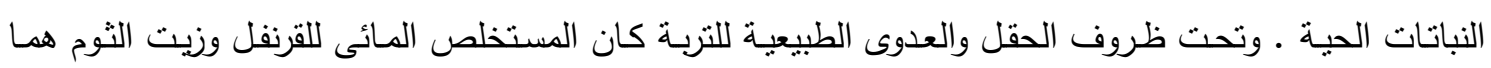

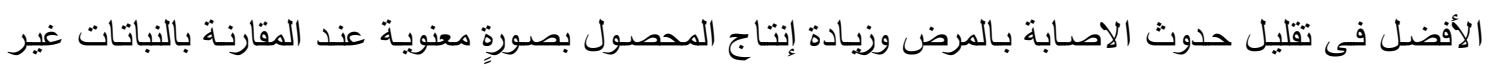

المعاملة فى صنف الفاصوليا تحت الدراسة جيزه 3 ـ 